\title{
Staphylococcal-Produced Bacteriocins and
} Antimicrobial Peptides: Their Potential as Alternative Treatments for Staphylococcus aureus Infections

\author{
Logan L. Newstead ${ }^{1}$, Katarina Varjonen ${ }^{2}$, Tim Nuttall ${ }^{1}$ and Gavin K. Paterson ${ }^{1, *(1)}$ \\ 1 Royal (Dick) School of Veterinary Studies and The Roslin Institute, University of Edinburgh, Easter Bush \\ Campus, Midlothian EH25 9RG, UK; L.Newstead@sms.ed.ac.uk (L.L.N.); Tim.Nuttall@ed.ac.uk (T.N.) \\ 2 AniCura Djursjukhuset Albano, Rinkebyvägen 21A, 18236 Danderyd, Sweden; \\ katarina.varjonen@anicura.se \\ * Correspondence: gavin.paterson@ed.ac.uk
}

Received: 9 December 2019; Accepted: 19 January 2020; Published: 21 January 2020

\begin{abstract}
Staphylococcus aureus is an important pathogen of both humans and animals, implicated in a wide range of infections. The emergence of antibiotic resistance has resulted in S. aureus strains that are resistant to almost all available antibiotics, making treatment a clinical challenge. Development of novel antimicrobial approaches is now a priority worldwide. Bacteria produce a range of antimicrobial peptides; the most diverse of these being bacteriocins. Bacteriocins are ribosomally synthesised peptides, displaying potent antimicrobial activity usually against bacteria phylogenetically related to the producer strain. Several bacteriocins have been isolated from commensal coagulase-negative staphylococci, many of which display inhibitory activity against $S$. aureus in vitro and in vivo. The ability of these bacteriocins to target biofilm formation and their novel mechanisms of action with efficacy against antibiotic-resistant bacteria make them strong candidates as novel therapeutic antimicrobials. The use of genome-mining tools will help to advance identification and classification of bacteriocins. This review discusses the staphylococcal-derived antimicrobial peptides displaying promise as novel treatments for S. aureus infections.
\end{abstract}

Keywords: bacteriocins; antimicrobial peptides; Staphylococcus; Staphylococcus aureus; MRSA

\section{Introduction}

Staphylococcus aureus is a frequent opportunistic pathogen of humans and animals that is capable of causing a variety of infections including skin and soft tissue infections, mastitis, urinary tract infections (UTIs), osteomyelitis, meningitis, food poisoning, biofilm-associated infections or septicaemia [1-3]. These can range from trivial and self-limiting to severe and life-threatening. S. aureus is a leading cause of nosocomial infections, implicated in $30 \%$ of infectious endocarditis cases [4,5], and the second most common cause of hospital-acquired pneumonia [6,7]. However, S. aureus is also a commensal organism, with $20-30 \%$ of humans persistently colonised nasally by the bacteria [8-10]. There is an epidemiological link between nasal carriage of $S$. aureus and subsequent infection with the carriage strain, especially among hospitalised individuals $[9,11]$. Risk factors for $S$. aureus infection include prolonged hospitalisation (especially intensive care), surgery, orthopedic and nursing implants, compromised immunity, skin barrier defects, and inflammatory diseases such as atopic dermatitis. The pathogenicity of $S$. aureus is attributed to an array of virulence factors, which include toxins such as enterotoxins, exfoliative toxins, and Panton-Valentine leucocidin (PVL) $[12,13]$. S. aureus can cause disease in healthy individuals as a result of expression of these virulence factors [1,13]. S. aureus also has the ability to form biofilms both on medically implanted devices and on tissue [14]; these characteristics allow 
S. aureus to invade tissue and disseminate, causing systemic disease. The emergence of antimicrobial resistance makes the treatment of $S$. aureus infections a clinical challenge, with many strains displaying methicillin-resistance (MRSA) or multidrug resistance (MDR) [15]. Methicillin-resistance is typically mediated by mec $A$, or less frequently by mec $C$, located on the staphylococcal chromosomal cassette mec (SCCmec), and is associated with resistance to virtually all $\beta$-lactam antibiotics [15-17]. Multidrug resistance is typically defined as acquired resistance to three or more classes of antibiotic, with some S. aureus strains possessing resistance to all available antibiotics [18]. Topical mupirocin application is often used to eradicate nasal MRSA colonisation pre-operatively to prevent infections, however there are reports of increasing mupirocin resistance [19]. As such, finding alternative treatments for MRSA infections is a public health priority worldwide [20].

S. aureus, including MRSA, can be isolated from healthy and diseased animals, from companion animals to livestock [21-24]. S. aureus infection has serious welfare implications; some of the most severe infections can be seen in food animals, such as poultry, where the bacteria can cause comb necrosis, chondronecrosis and septicaemia [25,26], and in dairy cattle, where it is one of the causative agents of mastitis $[27,28]$. S. aureus causes chronic, sub-clinical intramammary infection in cattle, resulting in increased somatic cell count in the milk, and as such, decreased milk quality, in addition to decreased milk yield, increased veterinary and labour costs, and loss due to culling [27-29]. As a result, bovine mastitis is one of the most economically important diseases in animals. Colonisation and infection in animals also poses a threat to human health, so called livestock-associated MRSA (LA-MRSA), due to the risk of zoonotic transmission, via the food chain or through direct contact [30]. This represents the third recognised epidemiological form of human MRSA along with hospital-associated MRSA (HA-MRSA) and community-associated MRSA (CA-MRSA). Holistic approaches such as improved biosecurity on farms, vaccine development, and selective breeding for animals resistant to pathogens, have yet to succeed in the control of S. aureus infections in animals [31-35], increasing the urgent need for the development of novel antimicrobials.

\section{Bacteriocins as Novel Antimicrobials}

In recent years, the importance of the natural microbiota in health and disease has been highlighted [20,36-40]. In particular, the normal diverse healthy-state microbiota may help regulate inflammation and help prevent colonisation and invasion by potentially pathogenic organisms [41]. One of the ways by which commensal bacteria regulate colonisation by invasive pathogens is via bacteriocin production [20]. Bacteriocins are ribosomally synthesised peptides that display antimicrobial activity against bacteria closely related to the producer strain, but to which the producer strain itself is resistant $[42,43]$. Bacteriocin resistance genes are typically present concomitantly with bacteriocin structural genes. The mechanisms of resistance include antagonistic bacteriocin receptors or specialised ATP-binding cassette efflux transporters [43-45]. As the target strains and producer strains typically share an ecological niche, these specific resistance mechanisms contribute to producer strain survival [43,46-48]. Bacteriocin production is an important trait for bacterial fitness, allowing competition against other microorganisms within a niche [49]. However, bacteriocin activity is more complex, with some shown to act as signaling peptides in both quorum sensing systems or interaction with the host immune system [48,50,51]. Some bacteriocins are multifunctional, such as BacSp222 produced by Staphylococcus pseudintermedius 222, which features bacteriocin activity, cytotoxicity towards eukaryotic cells and immunomodulating properties [52]. The seeming ubiquity of bacteriocins, despite the energetic costs of production, supports the theory that they are important to bacterial success beyond their role as antimicrobial peptides, and up to $99 \%$ of bacteria are thought to produce at least one bacteriocin [53]. Bacteriocins have become an important target in the search for novel antimicrobials as a result of their abundance and activity against a range of pathogens.

Bacteriocins possess several advantages over traditional antibiotics as a treatment for bacterial infections. Firstly, they typically possess a very narrow spectrum of activity, resulting in less disruption to the microbiota, which can increase susceptibility to pathogenic invasion and has been 
associated with several inflammatory or metabolic diseases [54]. Narrow spectrum antimicrobials also generate less selective pressure for the development of resistance in non-target organisms [55]. The mechanism of action of bacteriocins is distinct from most antibiotics, meaning they are effective against antibiotic-resistant strains of bacteria [56]. Many bacteriocins are also able to target quiescent cells as well as those actively dividing [57,58]. As ribosomally synthesised peptides, they are amenable targets for bioengineering, and can be modified relatively easily to improve characteristics such as potency, solubility, and stability [56,59]. They also show antimicrobial activity at very low concentrations compared to antibiotics (typically nanomolar concentrations) [46]. As peptides, they are susceptible to digestive enzymes; this improves their safety and minimizes disruption to the gastrointestinal microbiota but might limit them to parenteral or topical administration [54]. Several bacteriocins, such as nisin, have been approved for use as food bio-preservatives and granted generally regarded as safe (GRAS) status [60,61]. However, despite their use in the food industry, it is only recently that attention has been turned to potential use of bacteriocins as alternative antimicrobial therapies. Many Staphylococcus species have been shown to produce bacteriocins (Table 1), although bacteriocin production is a strain-specific, not a species-specific, trait [62]. Coagulase-negative Staphylococcus spp. (CoNS) are commonly found in the commensal skin microbiota [63]. As bacteriocins typically display antimicrobial activity against strains closely phylogenetically related or within the same niche as the producer, staphylococcal bacteriocins (referred to as staphylococcins) could be promising candidates for the treatment of $S$. aureus infections $[64,65]$. This review will explore fully and partially characterised staphylococcins, and their therapeutic potential as novel alternatives to traditional antimicrobials in the treatment of $S$. aureus infections.

\section{Staphylococcins}

A large number of bacteriocins have been isolated from Staphylococcus species. S. aureus is a prolific bacteriocin producer, with approximately 10 bacteriocins and bacteriocin-like inhibitory substances (BLIS) identified $[46,66,67]$. Six well-characterised bacteriocins have been isolated from Staphylococcus epidermidis [46,64,68-70]. Many other CoNS produce bacteriocins, and several have been shown to exert inhibitory activity against $S$. aureus, making them promising candidates for further research. Gram-positive bacterial derived bacteriocins tend to be highly cationic heat stable molecules [71,72]. Staphylococins are most commonly encoded on plasmids or other mobile genetic elements, although they can be chromosomally encoded [51,73].

Gram-positive and Gram-negative bacteriocins have distinct classification systems; there are four classes of Gram-positive bacteriocins, each containing several sub-classes (Figure 1) [46,74]. The majority of staphylococcins belong to class Ia, also known as lantibiotics. These are small $(<5 \mathrm{kDa})$, post-translationally modified peptides, containing lanthionine or $\beta$-methyllanthionine residues $[43,71]$, and possess relatively broad spectrum activity for bacteriocins, typically demonstrating antimicrobial activity against a range of Gram-positive organisms [71]. Lantibiotics are the most extensively studied class of bacteriocins, and as a result, their mechanism of action is relatively well understood. The majority of lantibiotics cause bacterial cell lysis and death via membrane potential-dependent permeabilisation or transmembrane pore formation $[51,75,76]$. The lantibiotic epidermin and its natural variant gallidermin can also inhibit peptidoglycan biosynthesis by binding membrane-bound lipid II, a peptidoglycan precursor [56,77-79]. These bacteriocins bind distinct sites from those targeted by the antibiotic vancomycin, allowing them to maintain efficacy against vancomycin-resistant bacterial strains [80]. The epidermin group of bacteriocins also have the potential to inhibit biofilm formation due to their ability to disrupt teichoic acid biosynthesis [75,81]. Pep5, a bacteriocin produced by S. epidermidis, binds negatively charged lipoteichoic acids, initiating autolysis of the target cell due to release and activation of cell wall hydrolysing enzymes [51]. This demonstrates that bacteriocins can inhibit target strains through several mechanisms, both bacteriostatic and bactericidal. 

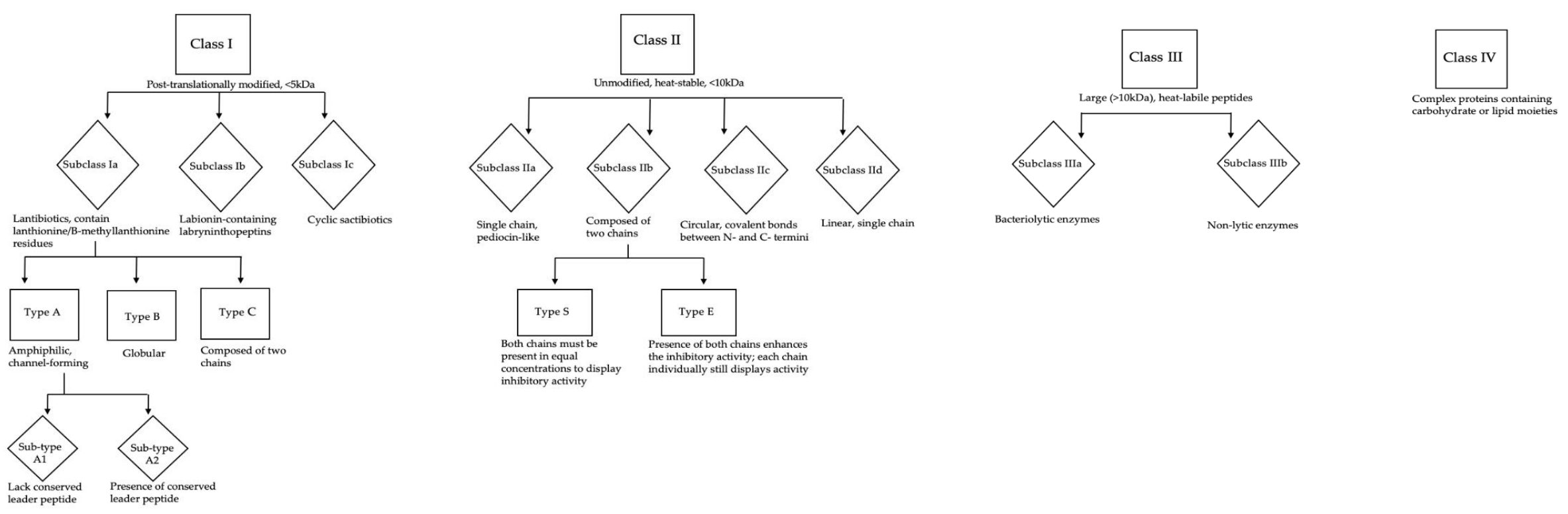

Figure 1. Classification of Gram positive-derived bacteriocins. 
Subclass Ic, the sactibiotics, are extensively post-translationally modified bacteriocins characterised by the presence of cross-links between the thiol group of cysteine residues and the $\alpha$-carbon of acceptor amino acids [42,82]. Only a handful of sactibiotics have been characterised, nearly all from Bacillus spp. However the first staphylococcal-derived sactibiotic, hyicin 4244, was recently discovered by Freitas De Souza Duarte et al. [83]. Many of the first described sactibiotics were circular, leading to the initial classification of sactibiotics as class IV [84]. However, the existence of linear sactibiotics has resulted in some discrepancy regarding the position of sactibiotics within bacteriocin nomenclature; it has been suggested they represent a novel class, class $\mathrm{V}$, but currently they are tentatively considered a subgroup of class I $[84,85]$. As more sactibiotics are isolated and characterised, a robust classification of these substances may be elucidated.

The remaining classes of bacteriocin are not as well characterised as the class I peptides. Class II, compromised of four subclasses, contains fewer members than seen in class I. Most belong to class IId; linear, single chain peptides, typically unmodified and of molecular mass below $10 \mathrm{kDa}$ [66]. Class IIb contains bacteriocins composed of two chains. These bacteriocins can be further defined as type E, where both components show inhibitory activity alone but the presence of both enhances this activity. However, the two class IIlb staphylococcins (C55 and aureocin A70 both produced by S. aureus) are type $\mathrm{S}$ (synergy) meaning that both chains must be present in equimolar proportions for bacteriocin activity $[46,72]$.

Class III bacteriocins are large $(>10 \mathrm{kDa})$, heat-labile proteins in two sub-classes; IIIa, the bacteriolytic enzymes, and IIIb, non-lytic enzymes [81,86]. The in vitro and in vivo efficacy of lysostaphin, a class IIIa metalloprotease, against a range of pathogens has been studied since the 1960s [87]. The catalytic domain of lysostaphin has three distinct functions (a glycylglycine endopeptidase, an endo-B-N-acetyl glucoamidase, and an $\mathrm{N}$-acetyl-muramyl-L-alanine amidase) allowing it to hydrolyse peptidoglycan components, particularly pentaglycine cross-links $[88,89]$. These are not typically seen in CoNS, making lysostaphin specific for actively growing and quiescent S. aureus [88-90].

Class IV is the final class of staphylococcins. These bacteriocins are poorly characterised and complex proteins, containing carbohydrate or lipid moieties [46,91]. Currently there is only one known staphylococcin in this group; aureocyclicin 4185, isolated from S. aureus 4185 . This is a cyclic bacteriocin, thought to be cationic, with high hydrophobic residue content. There is little known about its mechanism of action or spectrum of activity [91].

Whilst several staphylococcins have been well characterised (Table 1), there are also many other that are only partially characterised with undefined structures, genetics and activities. Few have been tested for antimicrobial activity against pathogens, although some produced by CoNS have shown promising anti-S. aureus activity in vitro and in vivo. 
Table 1. Well-characterised bacteriocins isolated from Staphylococcus species.

\begin{tabular}{|c|c|c|c|c|c|c|c|}
\hline Class & Subclass & Subtype & Bacteriocin & Producing Strain & Inhibits S. aureus: Strain (MIC) & in vivo Model & References \\
\hline \multirow[t]{13}{*}{ I } & \multirow[t]{12}{*}{ Ia } & \multirow[t]{10}{*}{ A1 } & BacCh91* & S. aureus $\mathrm{CH} 9 / \mathrm{DSM} 26258$ & \multirow[t]{2}{*}{$\begin{array}{l}\text { in vitro: ATCC25923, Newman, } \\
\text { M-122, RN4220 }(4.0-6.0 \mu \mathrm{M})\end{array}$} & & [92] \\
\hline & & & Epicidin $280 *$ & S. epidermidis BN280 & & & {$[70]$} \\
\hline & & & Epidermin * & S. epidermidis Tü3298 & \multirow[t]{3}{*}{ in vitro } & & {$[74,93]$} \\
\hline & & & Epilancin $15 X^{*}$ & S. epidermidis $15 \mathrm{X} 154$ & & & [94] \\
\hline & & & Epilancin $\mathrm{K} 7$ * & S. epidermidis $\mathrm{K} 7$ & & & [69] \\
\hline & & & Gallidermin * & S. gallinarum F16/P57 Tü3298 & $\begin{aligned} \text { in vitro: } & \text { ATCC29213, CCUG35601 } \\
& (1.25-8.0 \mu \mathrm{g} / \mathrm{mL})\end{aligned}$ & & {$[75,95,96]$} \\
\hline & & & Hominicin & S. hominis MBBL2-9 & $\begin{array}{c}\text { in vitro: ATCC25923, ATCC11435, } \\
\text { CCAR M3501 (0.06-3.82 } \mu \mathrm{g} / \mathrm{mL})\end{array}$ & & {$[97,98]$} \\
\hline & & & Hyicin 3682 & S. hyicus 3682 & in vitro & & {$[99,100]$} \\
\hline & & & Nisin J & S. capitis APC2923 & in vitro & & {$[20]$} \\
\hline & & & Pep5 & S.epidermidis 5 & in vitro & & {$[73,74,93]$} \\
\hline & & \multirow[t]{2}{*}{ A2 } & Nukacin ISK-1 ** & $\begin{array}{l}\text { S. warneri Nukadoko/S. simulans } \\
3299\end{array}$ & & & {$[101]$} \\
\hline & & & Warnericin RB4 & S. warneri RB4 & & & [102] \\
\hline & Ic & & Hyicin 4244 & S. hyicus 4244 & in vitro & & {$[83,103]$} \\
\hline \multirow[t]{4}{*}{ II } & \multirow[t]{2}{*}{$\mathrm{Ilb}$} & $\mathrm{S}$ & Aureocin A70 & S. aureus A70 & & & [104] \\
\hline & & $\mathrm{S}$ & C55* & S. aureus C55 & & & [67] \\
\hline & \multirow[t]{2}{*}{ IId } & & Aureocin A53* & S. aureus A53 & & & {$[66,74]$} \\
\hline & & & BacSp222 ** & S.pseudintermedius & $\begin{array}{c}\text { in vitro: DSM26258, MRSA } \\
\text { USA300, KB/8568, ATCC25923 } \\
(0.89-1.30 \mu \mathrm{M})\end{array}$ & & [52] \\
\hline \multirow[t]{2}{*}{ II } & \multirow[t]{2}{*}{ IId } & & Capidermicin & S. capitis CIT060 & \multirow{3}{*}{ 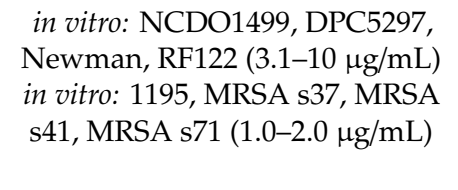 } & \multirow{3}{*}{$\begin{array}{l}\text { greater wax } \\
\text { moth, cotton rat }\end{array}$} & [105] \\
\hline & & & Epidermicin NI01* & S. epidermidis 224 & & & {$[64,106,107]$} \\
\hline \multirow[t]{2}{*}{ III } & IIIa & & Endopeptidase ALE-1 ${ }^{\dagger}$ & S. capitis EPk1 & & & [108] \\
\hline & & & Lysostaphin ** & $\begin{array}{l}\text { S. simulans biovar Staphylolyticus } \\
\text { ATCC1362 }\end{array}$ & in vitro $(0.002-100 \mu \mathrm{g} / \mathrm{mL})$ & $\begin{array}{c}\text { rat, mouse, } \\
\text { cotton rat, rabbit, } \\
\text { human }\end{array}$ & {$[87,88,90,109-119]$} \\
\hline IV & & & Aureocyclicin 4185 & S. aureus 4185 & & & [91] \\
\hline
\end{tabular}

Chemical structure available from: ${ }^{*}$ https://www.bactibase.hammamilab.org; ${ }^{* *}$ https://www.ncbi.nlm.nih.gov/Structure; $\mathbf{t}$ https://www.rcsb.org; all other chemical structures available from references stylised in bold. 


\subsection{Studies Showing in vitro Inhibitory Activity against Staphylococcus aureus}

Multiple techniques have been used to screen bacterial isolates for bacteriocin production in vitro. These include spot-on lawn assays where test producer strains are pipetted in small volumes onto the surface of agar plates, which are overlaid with soft agar containing the indicator (target) strain. Well-diffusion assays can be carried out using whole bacteria or, more commonly, cell-free supernatants $[74,120]$. The limitation of these assays is that they cannot discriminate between inhibitory activity due to bacteriocins or other antimicrobial substances, such as phenol-soluble modulins or organic acids [51]. The use of whole live bacteria also limits the quantitative data that can be obtained, as these assays cannot provide a minimum inhibitory or bactericidal concentration (MIC/MBC). Some studies utilise inhibition zone or density measurements to calculate arbitary units (AU) of inhibition, however these measurements are hard to standardise and are of less value than MICs. Partially purified protein and peptide antimicrobial substances are often tested for stability and activity under different conditions, such as $\mathrm{pH}$, temperature and following proteolytic digestion by enzymes such as proteinase K or trypsin. Proteolysis-associated loss of activity confirms their protein or peptide structure [43]. Based on these results it is then reasonable to presume the antimicrobial substance is a bacteriocin-like inhibitory substance (BLIS), however, molecular and genomic analysis should be carried out to confirm the molecule is a bacteriocin and further characterise and classify it.

The lantibiotics Pep5 and epidermin, both produced by Staphylococcus epidermidis, were shown to inhibit 14 and 13 of 16 test strains of S. aureus, respectively, including the endemic Brazilian MRSA clone A/22C. Pep5 also inhibited a mupirocin-resistant strain [74]. Further studies showed that Pep5 inhibited $63 \%$ and epidermin $87 \%$ of 165 S. aureus isolates from bovine mastitis cases in South America [85]. Hyicin 3682 from S. hyicus, a member of the epidermin-like group, inhibited 15 of 16 S. aureus test strains $[99,100]$. Hominicin from $S$. hominis displayed potent activity against multiple strains including S. aureus ATCC 25923, MRSA ATCC 11435, and vancomycin-intermediate S. aureus CCARM 3501 [97,98], at MICs of $0.06 \mu \mathrm{g} / \mathrm{mL}, 0.96 \mu \mathrm{g} / \mathrm{mL}$, and $3.82 \mu \mathrm{g} / \mathrm{mL}$, respectively [98]. BacCh91, produced by $S$. aureus CH91, inhibited four test strains of S. aureus (ATCC25293, Newman, M-122 and RN4220), with an MIC of 4.0-6.0 $\mathrm{MM}$ [92]. Gallidermin, isolated from poultry-associated Staphylococcus gallinarum, has been shown to be bactericidal against both MRSA and methicillin-sensitive S. aureus (MSSA) [96,121]. Gallidermin demonstrated both an MIC and MBC of $1.25 \mu \mathrm{g} / \mathrm{mL}$ against MSSA, and $1.56 \mu \mathrm{g} / \mathrm{mL}$ against MRSA [96]. Gallidermin was also able to inhibit biofilm formation of S. aureus SA113 at $0.16 \times$ the MIC [75]. Biofilm inhibition by gallidermin is due to repression of biofilm related genes atl and ica, encoding autolysin and polysaccharide intercellular adhesin (PIA), respectively. These gene products are involved in attachment to surfaces and cell aggregation, important steps in biofilm formation. However, gallidermin was not as effective against pre-formed biofilms, requiring $8 \times$ MIC to display inhibitory activity with $0.1-1.0 \%$ 'persister' cells still remaining [75]. The activity against planktonic cells and biofilm formation at low concentrations combined with the absence of cytotoxicity against fibroblasts or peripheral blood mononuclear cells, suggests gallidermin is a promising candidate as a therapeutic antimicrobial agent.

Recently, a natural variant of the lantibiotic nisin (nisin J) was isolated from Staphylococcus capitis APC2923 [122]. Nisin is a well-characterised bacteriocin first isolated from Lactococcus lactis; there are now at least ten known natural nisin variants produced by various Lactococcus, Streptococcus and Blautia spp. [123-128]. Nisin J appears resemble streptococcal nisin variants more closely than lactococcal variants [122]. Nisin J inhibited staphylococcal isolates, including S. aureus, with greater efficacy than nisin A or Z [122]. Like other nisin variants, the nisin J-encoding gene cluster resides on a plasmid; this has led to the suggestion that the gene cluster has been acquired via horizontal gene transfer, possibly explaining why nisin variants are isolated from several species [122].

A bacteriocin produced by Staphylococcus hyicus 4244 (hyicin 4244) was shown to have inhibitory activity against other staphylococcal species [83]. This bacteriocin inhibited ten clinical S. aureus isolates from humans and cattle, and demonstrated efficacy against MRSA and MDR strains. Hyicin 4244 also 
showed potential as an S. aureus biofilm-inhibiting agent. Genome analysis and further characterisation showed it belonged to class Ic, the sactibiotics [103], the first staphylococcin in this subclass.

BacSp222 is a class II staphylococcin produced by S. pseudintermedius [52]. This tryptophan residue rich bacteriocin showed no resemblance in peptide sequence to other bacteriocins beyond limited similarities to class II bacteriocins such as epidermicin NI01 and lacticin Q and Z. BacSp222 inhibited four S. aureus test strains, including MRSA and S. aureus CH91, the producer strain of bacteriocin BacCH91, with an MIC of 0.89-1.30 $\mathrm{MM}$. BacSp222 possesses some unusual characteristics for a bacteriocin; it is resistant to protease digestion and is active against the producer strain, although the MIC required $(2.1 \mu \mathrm{M})$ was much higher than the MIC against a non-producer $S$. pseudintermedius strain $(0.16 \mu \mathrm{M})$. Capidermicin and epidermicin NI01 are also class II bacteriocins, both belonging to the aureocin A53-subgroup [64,105]. Capidermicin inhibited all four test strains of S. aureus (NCDO1499, DPC5297, Newman, and RF122) with an MIC of 3.1-10 $\mu \mathrm{g} / \mathrm{mL}$, as well as S. pseudintermedius (MIC $10 \mu \mathrm{g} / \mathrm{mL}$ ) [105]. Epidermicin NI01 inhibited MRSA in vitro and was not toxic to erythrocytes or dermal fibroblasts, even at a concentration of 100× the MIC [64], making epidermicin NI01 a promising candidate treatment for $S$. aureus and S. pseudintermedius infections. The latter being a prominent pathogen in companion dogs, particularly in pyoderma [129], with antimicrobial resistance, including methicillin-resistance and MDR isolates presenting a challenge to treatment [130-132]. As with S. aureus, bacteriocins and related products may have a valuable role in new approaches to tackle this pathogen.

Many studies have demonstrated the efficacy of lysostaphin against $S$. aureus. Zygmunt et al. [114] showed lysostaphin inhibited 16 MRSA isolates with $4-8 \times$ the potency of synthetic $\beta$-lactams. Lysostaphin inhibited 111 clinical MRSA isolates in a study by Huber and Huber [116], with a subsequent study by von Eiff et al. [90] showing inhibition of 429 MRSA and MSSA strains, isolated from both commensal nasal swabs and cases of bacteraemia. Lysostaphin was also shown to kill biofilm-associated S. aureus cells and disrupt the biofilm extracellular matrix [115]. Catheters coated with lysostaphin showed complete clearance of S. aureus compared to control catheters, where an average of $493 \mathrm{CFU}$ were recovered. The inhibitory activity of lysostaphin was maintained on the catheters for at least four days post-coating, suggesting lysostaphin is able to bind to plastic surfaces and retain anti-staphylococcal activity for several days [111]. Due to this, lysostaphin has potential use as a preventative and treatment for biofilm-associated infections. The promising inhibitory activity of lysostaphin against $S$. aureus led to investigations of its efficacy in vivo.

\subsection{Models of in vivo Bacteriocin Therapy for Staphylococcus aureus Infection}

Animals are often used as models of human disease to determine the safety and efficacy of treatments under physiological conditions [133]. Lysostaphin has been widely tested in a range of in vivo systems. A single intravenous injection of lysostaphin decreased S. aureus bacterial load and increased survival rates in rodent models of infection, including mastitis, peritonitis and sepsis [117-119]. In mouse models of renal disease, a single intravenous dose of lysostaphin (from $1.56 \mathrm{mg} / \mathrm{kg}$ to 50 $\mathrm{mg} / \mathrm{kg}$ ) significantly reduced viable $S$. aureus bacterial counts from renal lesions by $95 \%$ compared to an untreated control [112], whilst another study showed a 39-78\% reduction in S. aureus bacterial burden and a 55-65\% decrease in mortality, dependent on the dose [113]. Rabbit models were used to test the efficacy of lysostaphin against $S$. aureus associated aortic valve endocarditis $[88,109]$. Both studies demonstrated a reduction in S. aureus counts following administration of lysostaphin, with a single dose showing a 3.7-6.63 $\log _{10}$ and $7.27-8.5 \log _{10}$ CFU/g decrease in bacterial counts compared to antibiotic-treated and untreated controls, respectively [88,109]. In one case, this result was seen three days post-treatment [109] whilst the second study noted that by $30 \mathrm{~h}$ post-treatment there was no difference in S. aureus counts between treated and control animals [88]. It is possible that the choice of vehicle and route of administration affects the duration of lysostaphin activity in vivo; this was further highlighted in a cotton rat model of $S$. aureus colonisation of the nares, where $0.5 \%$ lysostaphin in a petroleum-based vehicle eradicated MRSA and MSSA in 93\% of subjects whilst lysostaphin in a PBS solution resulted in eradication in only 33\% [57]. There has been a single trial of lysostaphin to 
eradicate nasal colonisation in humans comparing three treatment groups with an intranasal spray of $0.5 \%$ lysostaphin in saline $3 \times$ daily for five days, intranasal neomycin/polymyxin B/bacitracin spray $3 \times$ daily for five days, or no treatment [110]. 40\% of the lysostaphin-treated group were cleared of S. aureus colonisation, compared to $6 \%$ of the antibiotic-treated and $3 \%$ of the untreated group. The effect of lysostaphin appeared to be transient, however, with re-colonisation seen by Day 11 . It is possible that if delivered in a different vehicle, a longer-lived effect may be seen and this is a promising direction for further studies.

A relatively new model has been introduced for first-line in vivo testing, using Galleria mellonella (greater wax moth) larvae. These are an alternative to mammalian models as their immune system shows a high degree of structural and functional similarities to mammals [134]. These models are more accessible, inexpensive and ethical than using experimental mammals [106]. This model was used to test the efficacy and safety of epidermicin NI01 for S. aureus infection, which was non-toxic to the larvae and increased survival compared to untreated controls [106]. However, no quantified data for S. aureus bacterial burden before and after treatment was provided, which would be helpful in understanding its efficacy as an antimicrobial agent. Epidermicin NI01 was also tested in a cotton rat model of S. aureus nasal colonisation [107]; the nares of cotton rats structurally resemble those of humans, making it a useful model [135]. Subjects were treated with a single dose of $0.8 \%$ epidermicin NI01, twice daily treatment for three days with $0.04 \%$ epidermicin NI01, $0.2 \%$ epidermicin NI01, 2\% mupirocin, or a vehicle control. A single dose of $0.8 \%$ epidermicin NI01 was most effective, resulting in a significant reduction in nasal MRSA burden and eradication in three of five test subjects [107]. Epidermicin NI01 is therefore a potential novel therapeutic for S. aureus nasal colonisation.

\section{Other Antimicrobial Substances with Anti-Staphylococcus aureus Activity}

\subsection{Bacteriocin-Like Inhibitory Substances}

A partially purified antimicrobial substance has been derived from Staphylococcus pasteuri RSP-1 [65]. Cell-free supernatant (CFS) from S. pasteuri RSP-1 was found to inhibit 11 out of 14 S. aureus test strains [65]. Live-dead assays suggest this substance is bactericidal, causing membrane damage and subsequent cell death in target cells. Antimicrobial activity of the CFS was lost following proteolytic digestion, whilst nuclease, amylase and lipase had no effect, confirming the substance is proteinaceous. It was heat stable up to $121^{\circ} \mathrm{C}$ and at a range of $\mathrm{pH}$, although a gradual loss of activity was seen with increasing $\mathrm{pH}$. These characteristics are suggestive of a bacteriocin. The substance, named pasteuricin, has a molecular weight of $5 \mathrm{kDa}$ [65], suggesting it belongs to bacteriocin class I or II, but further characterisation is needed.

Staphylococcus capitis TE8 isolated from the skin microbiota of humans showed antimicrobial activity against a range of Gram-positive organisms, including S. aureus, but had no effect on Gram-negative organisms [136]. Partially purified CFS extract also demonstrated this activity, which was lost with proteinase K digestion, suggesting the inhibitory effect was mediated by production of a BLIS. Genomic analysis revealed $S$. capitis TE8 possesses multiple antimicrobial peptide (AMP) gene clusters, including those encoding an epidermicin-like peptide, a gallidermin-like peptide, and several phenol-soluble modulins [136]. The epidermicin-like peptide seen may be capidermicin, an epidermicin variant recently isolated from S. capitis CIT060 [105]. However, it is possible that the BLIS and gene-clusters possessed by $S$. capitis TE8 are novel bacteriocins.

Nakatsuji et al. [62] explored the abundance of AMP production in the skin microbiota of humans with atopic dermatitis (AD) and healthy controls; they found that AMPs were common in the microbial communities of healthy subjects, but not those with AD. The application of AMP-producing S. hominis or S. epidermidis to the skin of AD subjects significantly decreased S. aureus burden on the skin compared to untreated and vehicle-treated controls, supporting the protective role of AMP-producing CoNS within the skin microbiota. Further investigation of commensal CoNS isolates revealed a strain of S. hominis (A9) with potent antimicrobial activity against S. aureus. Application of S. hominis A9 to 
sanitised pig skin coated with $1 \times 10^{5} \mathrm{CFU} / \mathrm{cm}^{2}$ S. aureus or to mice colonised with $S$. aureus significantly decreased $S$. aureus counts, with application twice daily for one week eliminating $S$. aureus colonisation in the mouse model. In contrast, application of killed S. hominis A9 or a non-inhibitory control strain of S. hominis had no effect. Genomic and biochemical analysis revealed S. hominis A9 produces two AMPs, predicted to be lantibiotics based their on structure and amino acid composition. These AMPs, named Sh-lantibiotic- $\alpha$ and Sh-lantibiotic- $\beta$, were encoded within a gene cluster containing lanM, $\operatorname{lan} C$, and $\operatorname{lan} T$ homologs. These genes were not detected in non-inhibitory $S$. hominis strains. Purified $S h$-lantibiotic- $\alpha$ and Sh-lantibiotic- $\beta$ inhibited S. aureus on sanitised pig skin at a concentration of $0.5 \mathrm{nM}$, whilst concentrations up to $10 \mathrm{nM}$ had no effect on S. hominis A9, the producer strain. Sh-lantibiotic- $\alpha$ and $S h$-lantibiotic- $\beta$ were able to suppress clinical $S$. aureus isolates, including MRSA USA300, but had no effect on commensal species isolated from the skin such as Propionibacterium acnes, S. epidermidis, and Corynebacterium minutissimim. This potent anti-S. aureus activity with limited disruption to microbiota make $S h$-lantibiotic- $\alpha$ and $S h$-lantibiotic- $\beta$ promising candidates for further development as novel therapeutics for $S$. aureus infection in $\mathrm{AD}$ and other skin conditions.

\subsection{Inhibitory Staphylococcal Strains}

Several strains of CoNS inhibit S. aureus in agar-based antagonism assays. Although the antimicrobial substances responsible have not been isolated, most are presumed to be BLIS. Staphylococcus succinus AAS2 CFS potently inhibited S. aureus in well-diffusion assays [137]. Another study [138] found that 28 of 243 Staphylococcus isolates produced antimicrobial substances; all were susceptible to proteolytic digestion and thus classified as BLIS. BLIS-producing isolates included S. chromogenes, S. epidermidis, S. haemolyticus, S. pseudintermedius, S. aureus, and S. agnetis. All the BLIS-producing isolates harboured $n u k A$ or $b s a A 2$ genes, suggesting these BLIS are related to nukacin ISK-1 or Bsa (a member of the epidermin-like lantibiotics). Purification, classification, and further testing of the inhibitory activity against $S$. aureus is needed to determine their potential as anti-S. aureus agents. 77 of 89 Staphylococcus isolates from nasal swabs of 37 human volunteers were shown to have inhibitory activity [139]. These isolates belonged to six species: S. epidermidis, S. aureus, S. hominis, S. lugdunensis, S. warneri, and S. capitis. Only two of the total 77 strains, however, showed inhibitory activity against $S$. aureus. $96 \%$ of the $S$. epidermidis strains produced BLIS, but these were not further investigated to determine if they were novel or one of the already isolated bacteriocins from this species. A recent study demonstrated AMP production by 21 CoNS strains, belonging to five species; S. capitis, S. hominis, S. simulans and S. warneri [20]. Of these, four S. warneri strains and one S. hominis strain were able to inhibit S. aureus [20]. Two strains belonging to S. capitis, APC2934 and APC2918, were able to inhibit both S. aureus and MRSA test strains [20]. These strains did not possess the structural genes encoding nisin $\mathrm{J}$ and colony mass spectrometry did not match the peptides produced by these S. capitis strains to any listed on BACTIBASE [20], suggesting these are potentially novel bacteriocins.

Carson et al. [140] investigated 441 non-aureus staphylococci (NAS) isolates; 40 of the isolates showed inhibitory activity against a bovine mastitis S. aureus strain; of these, 23 also inhibited MRSA. These strains belonged to S. capitis, S. chromogenes, S. epidermidis, S. pasteuri, S. simulans and S. xylosus. Only five of these species inhibited S. aureus in well-diffusion assays using chloroform-extracted cell-free supernatant; all five supernatants were inactivated by proteinase $\mathrm{K}$, suggesting the active components are BLIS secreted by the bacteria. The genomes of the 441 NAS were studied for the presence of bacteriocin biosynthetic gene clusters. 105 clusters were identified from 95 NAS isolates, belonging to 16 species (Table 2), but there was no obvious clustering based on phylogeny or bacteriocin class. Ten of the NAS genomes encoded two clusters, belonging to different classes, suggesting these isolates have the potential to produce two bacteriocins [140]. This data shows that the 95 isolates possessing bacteriocin gene clusters have the potential to produce bacteriocins. However, only 40 of the isolates displayed inhibitory activity in vitro. The discrepancy between presence of bacteriocin genes and production of bacteriocins is likely due to the influence of growth conditions on bacteriocin production; the availability of nutrients, presence of stressors, temperature, and choice of media can all 
affect bacteriocin production [20]. This highlights the importance of screening methods when trying to identify bacteriocin-producing bacteria, suggesting that there may be many more strains capable of producing bacteriocins that have not yet been discovered. Genome-mining tools, such as antiSMASH and BAGEL [141,142], are able to identify bacteriocin gene clusters in bacterial genomes, highlighting those harbouring the potential to produce bacteriocins. These techniques will be invaluable in the search for novel bacteriocins especially as the availability of sequenced genomes increases.

Table 2. Strains of Staphylococcus found to harbour bacteriocin gene-clusters from 441 non-aureus Staphylococcus isolates analysed, the number of isolates possessing bacteriocin production genes that displayed inhibitory activity, and the number of isolates displaying in vitro inhibitory activity against S. aureus strains isolated from bovine mastitis cases. Each cluster encodes one bacteriocin [140].

\begin{tabular}{|c|c|c|c|c|}
\hline & \multicolumn{3}{|c|}{ Class I } & \multirow[t]{2}{*}{ Class II } \\
\hline & Lantibiotics & Sactibiotics & Lasso Peptides & \\
\hline $\begin{array}{l}\text { Number of Bacteriocin } \\
\text { Clusters Identified }\end{array}$ & 29 & 3 & 4 & 69 \\
\hline $\begin{array}{l}\text { Number of Isolates that the } \\
\text { Clusters are Present in }\end{array}$ & 29 & 3 & 2 & 68 \\
\hline $\begin{array}{c}\text { The Species that the Clusters } \\
\text { are Present in }\end{array}$ & $\begin{array}{l}\text { S. capitis } \\
\text { S. chromogenes } \\
\text { S. cohnii } \\
\text { S. epidermidis } \\
\text { S. equorum } \\
\text { S. gallinarum } \\
\text { S. sciuri } \\
\text { S. simulans } \\
\text { S. succinus } \\
\text { S. vitulinus }\end{array}$ & S. capitis & S. fleurettii & $\begin{array}{c}\text { S. equorum } \\
\text { S. gallinarum } \\
\text { S. haemolyticus } \\
\text { S. hyicus } \\
\text { S. saprophyticus } \\
\text { S. sciuri } \\
\text { S. simulans } \\
\text { S. succinus } \\
\text { S. warneri } \\
\text { S. xylosus }\end{array}$ \\
\hline $\begin{array}{l}\text { Number of Isolates Showing } \\
\text { Inhibitory Activity in vitro }\end{array}$ & 15 & 2 & 1 & 9 \\
\hline
\end{tabular}

\subsection{Staphylococcal-Produced Antimicrobial Substances}

Staphylococcus species produce a range of other secretory-AMPs (sAMPs) alongside bacteriocins, and several of these non-bacteriocin AMPs show promise as therapeutic agents for S. aureus infections. Esp is a serine protease produced by some S. epidermidis strains [143]. It was noted that presence of certain S. epidermidis strains within the nasal cavity appeared to influence $S$. aureus nasal colonisation. The CFS of these strains inhibited S. aureus in vitro, leading to the purification and identification of Esp. Application of purified Esp or Esp-producing S. epidermidis to the nasal cavities of S. aureus carriers eliminated $S$. aureus colonisation. Esp is effective against $S$. aureus biofilms, cleaving autolysin-derived murein hydrolases [144] and preventing the release of DNA, one of the structural components of S. aureus biofilm extracellular matrices $[145,146]$. Esp also targets $S$. aureus surface proteins, disrupting host-pathogen interactions [147], allowing Esp to be active against biofilm-forming and planktonic S. aureus cells. This suggests Esp could be a very promising antimicrobial agent.

Lugdunin is a novel antimicrobial, isolated from S. lugdunensis IVK28 [148]. It is only produced under iron-limiting conditions on solid agar, again highlighting the importance of growth conditions of producer strains when isolating antimicrobial substances. Lugdunin was encoded by all the S. lugdunensis strains analysed, suggesting production is species specific rather than strain specific [148]. Lugdunin is a complex, non-ribosomally synthesised peptide, containing a tryptophan moiety, with no resemblance to any known antimicrobial substances [148]. Lugdunin became the founding member of a new class of antibiotics, the thiazolidine-containing peptide antibiotics. It is suggested that it exerts its antimicrobial activity by depleting bacterial energy resources [148]. Lugdunin demonstrated potent inhibitory activity against a range of Gram-positive organisms, including MRSA and glycopeptide-intermediate S. aureus [148]. This antibiotic displayed no toxicity towards human 
neutrophils or erythrocytes, and retained activity in human serum. Lugdunin was also able to reduce or eradicate $S$. aureus in a mouse model [148]. Together these examples demonstrate the range of antimicrobial substances produced by commensal staphylococci, and their potential as novel treatments for $S$. aureus infection. It is highly likely more remain to be discovered.

\section{Conclusions and Future Directions}

The commensal bacteria residing in the microbiota play a vital role in protecting the host from invasion of pathogenic organisms. This protective activity is often mediated by bacteriocins, which are ribosomally synthesised peptides produced by bacteria that possess antimicrobial activity. Bacteriocins may be a valuable tool in the future fight against antimicrobial-resistant pathogens due to their novel mechanisms of action, narrow spectrum of activity, and ability to be bioengineered to improve specific qualities desirable in biopharmaceutical agents. Many bacteriocins produced by staphylococci display potent activity against $S$. aureus in vitro; however, the lack of cytotoxicity testing of many bacteriocins is a limitation when assessing their therapeutic usefulness. Although many bacteriocins demonstrate cytotoxicity against eukaryotic cells, often in a dose-dependent manner, this does not entirely eliminate their potential as candidates for treatment of $S$. aureus infections including those caused by methicillin-resistant strains in humans and animals. Thorough evaluation of potential cytotoxic effects and pharmacodynamics of the substance, weighed against its efficacy, is required to determine suitability as an anti-S. aureus agent. Genome-mining techniques will facilitate the search for bacteriocin-producing bacterial strains, overcoming some of the limitations of agar assay-based methods, and helping eliminate some discrepancy in the classification of these substances.

Elucidation of the mechanisms of action of bacteriocins, especially those belonging to classes II-IV, alongside further testing of their efficacy under physiological conditions is required to determine their suitability for therapeutic use. It is important to note that although resistance among target strains to these peptides has yet to be witnessed under laboratory conditions, resistance mechanisms are widespread in producer strains. Therefore, prudence must be exercised if and when bacteriocins and related products are utilised clinically to avoid the spread of resistance and loss of efficacy.

Author Contributions: Reviewed literature and prepared manuscript draft: L.L.N. Edited the paper: K.V., T.N. and G.K.P. Approved final version: all authors. All authors have read and agreed to the published version of the manuscript.

Funding: This study was funded by PetSavers, the charitable division of the BSAVA (grant MDR 05.18).

Conflicts of Interest: The authors declare no conflict of interest.

\section{References}

1. Lowy, F.D. Staphylococcus aureus infections. N. Engl. J. Med. 1998, 339, 520-532. [CrossRef]

2. Ellington, J.K.; Harris, M.; Webb, L.; Smith, B.; Smith, T.; Tan, K.; Hudson, M. Intracellular Staphyloccus aureus. J. Bone Jt. Surg. Ser. B 2003, 85, 918-921. [CrossRef]

3. Tong, S.Y.C.; Davis, J.S.; Eichenberger, E.; Holland, T.L.; Fowler, V.G. Staphylococcus aureus infections: Epidemiology, pathophysiology, clinical manifestations, and management. Clin. Microbiol. Rev. 2015, 28, 603-661. [CrossRef] [PubMed]

4. Fowler, V.G., Jr.; Miro, J.M.; Hoen, B.; Cabell, C.H.; Abrutyn, E.; Rubinstein, E.; Corey, G.R.; Spelman, D.; Bradley, S.F.; Barsic, B.; et al. Staphylococcus aureus endocarditis: A consequence of medical progress. JAMA 2005, 293, 3012-3021. [CrossRef] [PubMed]

5. Saeed, K.; Bal, A.M.; Gould, I.M.; David, M.Z.; Dryden, M.; Giannitsioti, E.; Hijazi, K.; Meisner, J.A.; Esposito, S.; Scaglione, F.; et al. An update on Staphylococcus aureus infective endocarditis from the International Society of Antimicrobial Chemotherapy (ISAC). Int. J. Antimicrob. Agents 2019, 53, 9-15. [CrossRef] [PubMed]

6. Pletz, M.W.; Burkhardt, O.; Welte, T. Nosocomial methicillin-resistant Staphylococcus aureus (MRSA) pneumonia: Linezolid or vancomycin?-Comparison of pharmacology and clinical efficacy. Eur. J. Med. Res. 2010, 15, 507-513. [CrossRef] [PubMed] 
7. Lesher, B.; Gao, X.; Chen, Y.; Liu, Z. Methicillin-resistant Staphylococcus aureus nosocomial pneumonia: Role of linezolid in the People's Republic of China. Clin. Outcomes Res. 2016, 8, 63-72. [CrossRef]

8. Kluytmans, J.; Van Belkum, A.; Verbrugh, H. Nasal carriage of Staphylococcus aureus: Epidemiology, underlying mechanisms, and associated risks. Clin. Microbiol. Rev. 1997, 10, 505-520. [CrossRef]

9. Von Eiff, C.; Becker, K.; Machka, K.; Stammer, H.; Peters, G. Nasal carriage as a source of Staphylococcus aureus bacteremia. N. Engl. J. Med. 2001, 344, 11-16. [CrossRef]

10. Weidenmaier, C.; Goerke, C.; Wolz, C. Staphylococcus aureus determinants for nasal colonization. Trends Microbiol. 2012, 20, 243-250. [CrossRef]

11. Wertheim, H.F.L.; Melles, D.C.; Vos, M.C.; Van Leeuwen, W.; Van Belkum, A.; Verbrugh, H.A.; Nouwen, J.L. The role of nasal carriage in Staphylococcus aureus infections. Lancet Infect. Dis. 2005, 5, 751-762. [CrossRef]

12. Otto, M. Staphylococcus aureus toxins. Curr. Opin. Microbiol. 2014, 17, 32-37. [CrossRef] [PubMed]

13. Powers, M.E.; Wardenburg, J.B. Igniting the Fire: Staphylococcus aureus Virulence Factors in the Pathogenesis of Sepsis. PLoS Pathog. 2014, 10, e1003871. [CrossRef] [PubMed]

14. Archer, N.K.; Mazaitis, M.J.; William Costerton, J.; Leid, J.G.; Powers, M.E.; Shirtliff, M.E. Staphylococcus aureus biofilms: Properties, regulation and roles in human disease. Virulence 2011, 2, 445-459. [CrossRef] [PubMed]

15. Magiorakos, A.-P.; Srinivasan, A.; Carey, R.B.; Carmeli, Y.; Falagas, M.E.; Giske, C.G.; Harbarth, S.; Hindler, J.F.; Kahlmeter, G.; Olsson-Liljequist, B.; et al. Multidrug-resistant, extensively drug-resistant and pandrug-resistant bacteria: An international expert proposal for interim standard definitions for acquired resistance. Clin. Microbiol. Infect. 2012, 18, 268-281. [CrossRef]

16. Paterson, G.K.; Harrison, E.M.; Holmes, M.A. The emergence of mecC methicillin-resistant Staphylococcus aureus. Trends Microbiol. 2014, 22, 42-47. [CrossRef] [PubMed]

17. Peacock, S.J.; Paterson, G.K. Mechanisms of Methicillin Resistance in Staphylococcus aureus. Annu. Rev. Biochem. 2015, 84, 577-601. [CrossRef] [PubMed]

18. Chambers, H.F.; DeLeo, F.R. Waves of resistance: Staphylococcus aureus in the antibiotic era. Nat. Rev. Microbiol. 2009, 7, 629-641. [CrossRef]

19. Thomas, D.G.; Wilson, J.M.; Day, M.J.; Russell, A.D. Mupirocin resistance in staphylococci: Development and transfer of isoleucyl-tRNA synthetase-mediated resistance In Vitro. J. Appl. Microbiol. 1999, 86, 715-722. [CrossRef]

20. O'Sullivan, J.N.; Rea, M.C.; O'Connor, P.M.; Hill, C.; Ross, R.P. Human skin microbiota is a rich source of bacteriocin-producing staphylococci that kill human pathogens. FEMS Microbiol. Ecol. 2019, 95. [CrossRef]

21. Weese, J.S. Methicillin-resistant Staphylococcus aureus in animals. ILAR J. 2010, 51, 233-244. [CrossRef] [PubMed]

22. Fluit, A.C. Livestock-associated Staphylococcus aureus. Clin. Microbiol. Infect. 2012, 18, 735-744. [CrossRef] [PubMed]

23. Paterson, G.K.; Larsen, A.R.; Robb, A.; Edwards, G.E.; Pennycott, T.W.; Foster, G.; Mot, D.; Hermans, K.; Baert, K.; Peacock, S.J.; et al. The newly described mecA homologue, mecALGA251, is present in methicillin-resistant Staphylococcus aureus isolates from a diverse range of host species. J. Antimicrob. Chemother. 2012, 67, 2809-2813. [CrossRef] [PubMed]

24. Haag, A.F.; Fitzgerald, J.R.; Penadés, J.R. Staphylococcus aureus in Animals. Microbiol. Spectr. $2019,7$. [CrossRef]

25. McNamee, P.T.; McCullagh, J.J.; Thorp, B.H.; Ball, H.J.; Graham, D.; McCullough, S.J.; McConaghy, D.; Smyth, J.A. Study of leg weakness in two commercial broiler flocks. Vet. Rec. 1998, 143, 131-135. [CrossRef]

26. McNamee, P.T.; Smyth, J.A. Bacterial chondronecrosis with osteomyelitis ('femoral head necrosis') of broiler chickens: A review. Avian Pathol. 2000, 29, 253-270. [CrossRef]

27. Tenhagen, B.A.; Köster, G.; Wallmann, J.; Heuwieser, W. Prevalence of mastitis pathogens and their resistance against antimicrobial agents in dairy cows in Brandenburg, Germany. J. Dairy Sci. 2006, 89, 2542-2551. [CrossRef]

28. Bradley, A.J.; Leach, K.A.; Breen, J.E.; Green, L.E.; Green, M.J. Survey of the incidence and aetiology of mastitis on diary farms in England and Wales. Vet. Rec. 2007, 160, 253-258. [CrossRef] [PubMed]

29. Barkema, H.W.; Schukken, Y.H.; Zadoks, R.N. Invited review: The role of cow, pathogen, and treatment regimen in the therapeutic success of bovine Staphylococcus aureus mastitis. J. Dairy Sci. 2006, 89, 1877-1895. [CrossRef] 
30. Kinross, P.T.N.; Petersen, A.; Skov, R.; Van Hauwermeiren, E.; Pantosti, A.; Laurent, F.; Voss, A.; Kluytmans, J.; Struelens, M.J.; Heuer, O.; et al. Livestock-associated meticillin-resistant Staphylococcus aureus (MRSA) among human MRSA isolates, European Union/European Economic Area countries, 2013. Euro Surveill. 2017, 22. [CrossRef]

31. Erskine, R.J. Vaccination Strategies for Mastitis. Vet. Clin. N. Am. Food Anim. Pract. 2012, 28, 257-270. [CrossRef] [PubMed]

32. Leitner, G.; Lubashevsky, E.; Glickman, A.; Winkler, M.; Saran, A.; Trainin, Z. Development of a Staphylococcus aureus vaccine against mastitis in dairy cows: I. Challenge trials. Vet. Immunol. Immunopathol. 2003, 93, 31-38. [CrossRef]

33. Keefe, G. Update on control of Staphylococcus aureus and Streptococcus agalactiae for management of mastitis. Vet. Clin. N. Am. Food Anim. Pract. 2012, 28, 203-216. [CrossRef] [PubMed]

34. Heringstad, B.; Klemetsdal, G.; Ruane, J. Selection for mastitis resistance in dairy cattle: A review with focus on the situation in the Nordic countries. Livest. Prod. Sci. 2000, 64, 95-106. [CrossRef]

35. Rupp, R.; Boichard, D. Genetics of resistance to mastitis in dairy cattle. Vet. Res. 2003, 34, 671-688. [CrossRef] [PubMed]

36. Götz, F.; Perconti, S.; Popella, P.; Werner, R.; Schlag, M. Epidermin and gallidermin: Staphylococcal lantibiotics. Int. J. Med. Microbiol. 2014, 304, 63-71. [CrossRef] [PubMed]

37. Round, J.L.; Mazmanian, S.K. The gut microbiome shapes intestinal immune responses during health and disease. Nat. Rev. Immunol. 2009, 9, 313-323. [CrossRef] [PubMed]

38. Hooper, L.V.; Littman, D.R.; Macpherson, A.J. Interactions between the microbiota and the immune system HHS Public Access. Science 2012, 336, 1268-1273. [CrossRef]

39. Cogen, A.L.; Nizet, V.; Gallo, R.L.; Richard Gallo, C.L. Skin microbiota: A source of disease or defence? NIH Public Access. Br. J. Dermatol. 2008, 158, 442-455. [CrossRef]

40. Rosenthal, M.; Goldberg, D.; Aiello, A.; Larson, E.; Foxman, B. Skin microbiota: Microbial community structure and its potential association with health and disease. Infect. Genet. Evol. 2011, 11, 839-848. [CrossRef]

41. Christensen, G.J.M.; Brüggemann, H. Bacterial skin commensals and their role as host guardians. Benef. Microbes 2014, 5, 201-215. [CrossRef] [PubMed]

42. Cotter, P.D.; Ross, R.P.; Hill, C.; Ross, R.P. Bacteriocins: Developing innate immunity for food. Food Microbiol. 2005, 3, 777-788. [CrossRef]

43. Jack, R.W.; Tagg, J.R.; Ray, B. Bacteriocins of gram-positive bacteria. Microbiol. Rev. 1995, 59, 171-200. [CrossRef] [PubMed]

44. Peschel, A.; Götz, F. Analysis of the Staphylococcus epidermidis genes epiF, $-E$, and -G involved in epidermin immunity. J. Bacteriol. 1996, 178, 531-536. [CrossRef] [PubMed]

45. Havarstein, L.S.; Diep, D.B.; Nes, I.F. A family of bacteriocin ABC transporters carry out proteolytic processing of their substrates concomitant with export. Mol. Microbiol. 1995, 16, 229-240. [CrossRef] [PubMed]

46. Mak, P. Staphylococcal Bacteriocins. In Pet-to-Man Travelling Staphylococci: A World in Progress; Elsevier: Amsterdam, The Netherlands, 2018; pp. 161-171. ISBN 9780128135488.

47. Shin, J.M.; Gwak, J.W.; Kamarajan, P.; Fenno, J.C.; Rickard, A.H.; Kapila, Y.L. Biomedical Applications of Nisin HHS Public Access. J. Appl. Microbiol. 2016, 120, 1449-1465. [CrossRef]

48. Dobson, A.; Cotter, P.D.; Paul Ross, R.; Hill, C. Bacteriocin production: A probiotic trait? Appl. Environ. Microbiol. 2012, 78, 1-6. [CrossRef]

49. Krismer, B.; Weidenmaier, C.; Zipperer, A.; Peschel, A. The commensal lifestyle of Staphylococcus aureus and its interactions with the nasal microbiota. Nat. Rev. Microbiol. 2017, 15, 675-687. [CrossRef]

50. Schauber, J.; Gallo, R.L. Antimicrobial peptides and the skin immune defense system. J. Allergy Clin. Immunol. 2008, 122, 261-266. [CrossRef]

51. Bastos, M.; Ceotto, H.; Coelho, M.; Nascimento, J. Staphylococcal Antimicrobial Peptides: Relevant Properties and Potential Biotechnological Applications. Curr. Pharm. Biotechnol. 2009, 10, 38-61. [CrossRef]

52. Wladyka, B.; Piejko, M.; Bzowska, M.; Pieta, P.; Krzysik, M.; Mazurek, Ł.; Guevara-Lora, I.; Bukowski, M.; Sabat, A.J.; Friedrich, A.W.; et al. A peptide factor secreted by Staphylococcus pseudintermedius exhibits properties of both bacteriocins and virulence factors. Sci. Rep. 2015, 5, 14569. [CrossRef] [PubMed]

53. Klaenhammer, T.R. Bacteriocins of lactic acid bacteria. Biochimie 1988, 70, 337-349. [CrossRef] 
54. Gálvez, A.; Abriouel, H.; López, R.L.; Omar, N. Ben Bacteriocin-based strategies for food biopreservation. Int. J. Food Microbiol. 2007, 120, 51-70. [CrossRef] [PubMed]

55. Fox, J.L. The business of developing antibacterials. Nat. Biotechnol. 2006, 24, 1521-1528. [CrossRef] [PubMed]

56. Cotter, P.D.; Ross, R.P.; Hill, C. Bacteriocins-a viable alternative to antibiotics? Nat. Rev. Microbiol. 2013, 11, 95-105. [CrossRef]

57. Kokai-Kun, J.F.; Walsh, S.M.; Chanturiya, T.; Mond, J.J. Lysostaphin cream eradicates Staphylococcus aureus nasal colonization in a cotton rat model. Antimicrob. Agents Chemother. 2003, 47, 1589-1597. [CrossRef]

58. Bastos, M.D.; Coutinho, B.G.; Coelho, M.L. Lysostaphin: A staphylococcal bacteriolysin with potential clinical applications. Pharmaceuticals 2010, 3, 1139-1161. [CrossRef]

59. Field, D.; Gaudin, N.; Lyons, F.; O'Connor, P.M.; Cotter, P.D.; Hill, C.; Ross, R.P. A bioengineered nisin derivative to control biofilms of Staphylococcus pseudintermedius. PLoS ONE 2015, 10, 1-17. [CrossRef]

60. Cleveland, J.; Montville, T.J.; Nes, I.F.; Chikindas, M.L. Bacteriocins: Safe, natural antimicrobials for food preservation. Int. J. Food Microbiol. 2001, 71, 1-20. [CrossRef]

61. Quinto, E.J.; Caro, I.; Villalobos-delgado, L.H.; Mateo, J.; De-mateo-silleras, B.; Redondo-del-r, P. Food Safety through Natural Antimicrobials. Antibiotics 2019, 81, 208. [CrossRef]

62. Nakatsuj, T.; Kim, J.-N.; Lockhart, A.; Nakatsuji, T.; Hata, T.R.; Dorrestein, P.C.; David, G.; Gallo, R.L.; Shafiq, F.; Latif, H.; et al. Antimicrobials from human skin commensal bacteria protect against Staphylococcus aureus and are deficient in atopic dermatitis. Sci. Transl. Med. 2017, 9, eaah4680. [CrossRef]

63. Otto, M. Staphylococcus colonization of the skin and antimicrobial peptides. Expert Rev. Dermatol. 2010, 5, 183-195. [CrossRef]

64. Sandiford, S.; Upton, M. Identification, characterization, and recombinant expression of epidermicin NI01, a novel unmodified bacteriocin produced by Staphylococcus epidermidis that displays potent activity against staphylococci. Antimicrob. Agents Chemother. 2012, 56, 1539-1547. [CrossRef]

65. Hong, J.; Kim, J.; Quan, L.H.; Heu, S.; Roh, E. Purification and characterization of pasteuricin produced by Staphylococcus pasteuri RSP-1 and active against multidrug-resistant Staphylococcus aureus. J. Food Prot. 2018, 81, 1768-1775. [CrossRef]

66. Netz, D.J.; Pohl, R.; Beck-Sickinger, A.G.; Selmer, T.; Pierik, A.J.; Bastos, M.C.; Sahl, H.G. Biochemical characterisation and genetic analysis of aureocin A53, a new, atypical bacteriocin from Staphylococcus aureus. J. Mol. Biol. 2002, 319, 745-756. [CrossRef]

67. Navaratna, M.A.; Sahl,H.G.; Tagg, J.R. Two-component anti-Staphylococcus aureus lantibiotic activity produced by Staphylococcus aureus C55. Appl. Environ. Microbiol. 1998, 64, 4803-4808. [CrossRef]

68. Augustin, J.; Rosenstein, R.; Wieland, B.; Schneider, U.; Schnell, N.; Engelke, G.; Entian, K.-D.; Götz, F. Genetic analysis of epidermin biosynthetic genes and epidermin-negative mutants of Staphylococcus epidermidis. Eur. J. Biochem. 1992, 204, 1149-1154. [CrossRef]

69. Van De Kamp, M.; Van Den Hooven, H.W.; Konings, R.N.H.; Bierbaum, G.; Sahl, H.-G.; Kuipers, O.P.; Siezen, R.J.; De Vos, W.M.; Hilbers, C.W.; Van De Ven, F.J.M. Elucidation of the Primary Structure of the Lantibiotic Epilancin K7 from Staphylococcus epidermidis K7: Cloning and Characterisation of the Epilancin-K7-Encoding Gene and NMR Analysis of Mature Epilancin K7. Eur. J. Biochem. 1995, 230, 587-600. [CrossRef]

70. Heidrich, C.; Pag, U.; Josten, M.; Metzger, J.; Jack, R.W.; Bierbaum, G.; Jung, G.; Sahl, H.G. Isolation, characterization, and heterologous expression of the novel lantibiotic epicidin 280 and analysis of its biosynthetic gene cluster. Appl. Environ. Microbiol. 1998, 64, 3140-3146. [CrossRef]

71. McAuliffe, O.; Ross, R.P.; Hill, C. Lantibiotics: Structure, biosynthesis and mode of action. FEMS Microbiol. Rev. 2001, 25, 285-308. [CrossRef]

72. Ennahar, S.; Sashihara, T.; Sonomoto, K.; Ishizaki, A. Class Ila bacteriocins: Biosynthesis, structure and activity. FEMS Microbiol. Rev. 2000, 24, 85-106. [CrossRef] [PubMed]

73. Kaletta, C.; Entian, K.D.; Kellner, R.; Jung, G.; Reis, M.; Sahl, H.G. Pep5, a new lantibiotic: Structural gene isolation and prepeptide sequence. Arch. Microbiol. 1989, 152, 16-19. [CrossRef] [PubMed]

74. Nascimento, J.S.; Ceotto, H.; Nascimento, S.B.; Giambiagi-DeMarval, M.; Santos, K.R.N.; Bastos, M.C.F. Bacteriocins as alternative agents for control of multiresistant staphylococcal strains. Lett. Appl. Microbiol. 2006, 42, 215-221. [CrossRef] [PubMed] 
75. Saising, J.; Dube, L.; Ziebandt, A.-K.; Voravuthikunchai, S.P.; Nega, M.; Götz, F. Activity of gallidermin on Staphylococcus aureus and Staphylococcus epidermidis biofilms. Antimicrob. Agents Chemother. 2012, 56, 5804-5810. [CrossRef]

76. Bierbaum, G.; Sahl, H.-G. Lantibiotics: Mode of Action, Biosynthesis and Bioengineering. Curr. Pharm. Biotechnol. 2009, 10, 2-18. [CrossRef]

77. de Freire Bastos, M.D.C.; Varella Coelho, M.L.; da Silva Santos, O.C. Resistance to bacteriocins produced by gram-positive bacteria. Microbiology 2015, 161, 683-700. [CrossRef]

78. Bonelli, R.R.; Schneider, T.; Sahl, H.G.; Wiedemann, I. Insights into in vivo activities of lantibiotics from gallidermin and epidermin mode-of-action studies. Antimicrob. Agents Chemother. 2006, 50, 1449-1457. [CrossRef]

79. Brötz, H.; Josten, M.; Wiedemann, I.; Schneider, U.; Götz, F.; Bierbaum, G.; Sahl, H.G. Role of lipid-bound peptidoglycan precursors in the formation of pores by nisin, epidermin and other lantibiotics. Mol. Microbiol. 1998, 30, 317-327. [CrossRef]

80. Piper, C.; Draper, L.A.; Cotter, P.D.; Ross, R.P.; Hill, C. A comparison of the activities of lacticin 3147 and nisin against drug-resistant Staphylococcus aureus and Enterococcus species. J. Antimicrob. Chemother. 2009, 64, 546-551. [CrossRef] [PubMed]

81. Müller, E.; Radler, F. Caseicin, a bacteriocin from Lactobacillus casei. Folia Microbiol. 1993, 38, 441-446. [CrossRef]

82. Alvarez-Sieiro, P.; Montalbán-López, M.; Mu, D.; Kuipers, O.P. Bacteriocins of lactic acid bacteria: Extending the family. Appl. Microbiol. Biotechnol. 2016, 100, 2939-2951. [CrossRef] [PubMed]

83. de Souza Duarte, A.F.; Ceotto, H.; Coelho, M.L.V.; de Paiva Brito, M.A.V.; de Freire Bastos, M.C. Identification of new staphylococcins with potential application as food biopreservatives. Food Control 2013, 32, 313-321. [CrossRef]

84. Arnison, P.G.; Bibb, M.J.; Bierbaum, G.; Bowers, A.A.; Bugni, T.S.; Bulaj, G.; Camarero, J.A.; Campopiano, D.J.; Challis, G.L.; Clardy, J.; et al. Ribosomally synthesized and post-translationally modified peptide natural products: Overview and recommendations for a universal nomenclature. Nat. Prod. Rep. 2013, 30, 108-160. [CrossRef] [PubMed]

85. Varella Coelho, M.L.; Santos Nascimento, J.D.; Fagundes, P.C.; Madureira, D.J.; Oliveira, S.S.; Vasconcelos de Paiva Brito, M.A.; Freire Bastos, M.C. Activity of staphylococcal bacteriocins against Staphylococcus aureus and Streptococcus agalactiae involved in bovine mastitis. Res. Microbiol. 2007, 158, 625-630. [CrossRef]

86. Joerger, M.C.; Klaenhammer, T.R. Characterization and purification of helveticin J and evidence for a chromosomally determined bacteriocin produced by Lactobacillus helveticus 481. J. Bacteriol. 1986, 167, 439-446. [CrossRef]

87. Schindler, C.A.; Schuhardt, V.T. Lysostaphin: A new bacteriolytic agent for the staphylococcus. Proc. Natl. Acad. Sci. USA 1964, 51, 414-421. [CrossRef] [PubMed]

88. Climo, M.W.; Patron, R.L.; Goldstein, B.P.; Archer, G.L. Lysostaphin treatment of experimental methicillin-resistant Staphylococcus aureus aortic valve endocarditis. Antimicrob. Agents Chemother. 1998, 42, 1355-1360. [CrossRef]

89. Kiri, N.; Archer, G.; Climo, M.W. Combinations of lysostaphin with beta-lactams are synergistic against oxacillin-resistant Staphylococcus epidermidis. Antimicrob. Agents Chemother. 2002, 46, 2017-2020. [CrossRef]

90. Von Eiff, C.; Kokai-Kun, J.F.; Becker, K.; Peters, G. In Vitro Activity of Recombinant Lysostaphin against Staphylococcus aureus Isolates from Anterior Nares and Blood. Antimicrob. Agents Chemother. 2003, 47, 3613-3615. [CrossRef]

91. Potter, A.; Ceotto, H.; Coelho, M.L.V.; Guimarães, A.J.; Bastos, M.D.C.F. The gene cluster of aureocyclicin 4185: The first cyclic bacteriocin of Staphylococcus aureus. Microbiology 2014, 160, 917-928. [CrossRef]

92. Wladyka, B.; Wielebska, K.; Wloka, M.; Bochenska, O.; Dubin, G.; Dubin, A.; Mak, P. Isolation, biochemical characterization, and cloning of a bacteriocin from the poultry-associated Staphylococcus aureus strain CH-91. Appl. Microbiol. Biotechnol. 2013, 97, 7229-7239. [CrossRef]

93. Fontana, M.B.; de Bastos, M.C.; Brandelli, A. Bacteriocins Pep5 and epidermin inhibit Staphylococcus epidermidis adhesion to catheters. Curr. Microbiol. 2006, 52, 350-353. [CrossRef] [PubMed]

94. Ekkelenkamp, M.B.; Hanssen, M.; Hsu, S.T.D.; De Jong, A.; Milatovic, D.; Verhoef, J.; Van Nuland, N.A.J. Isolation and structural characterization of epilancin 15X, a novel lantibiotic from a clinical strain of Staphylococcus epidermidis. FEBS Lett. 2005, 579, 1917-1922. [CrossRef] [PubMed] 
95. Kellner, R.; Jung, G.; Hörner, T.; Zähner, H.; Schnell, N.; Entian, K.-D.; Götz, F. Gallidermin: A new lanthioninecontaining polypeptide antibiotic. Eur. J. Biochem. 2005, 177, 53-59. [CrossRef]

96. Bengtsson, T.; Lönn, J.; Khalaf, H.; Palm, E. The lantibiotic gallidermin acts bactericidal against Staphylococcus epidermidis and Staphylococcus aureus and antagonizes the bacteria-induced proinflammatory responses in dermal fibroblasts. Microbiologyopen 2018, 7, e00606. [CrossRef]

97. Sung, C.; Kim, B.G.; Kim, S.; Joo, H.S.; Kim, P.I. Probiotic potential of Staphylococcus hominis MBBL 2-9 as anti-Staphylococcus aureus agent isolated from the vaginal microbiota of a healthy woman. J. Appl. Microbiol. 2010, 108, 908-916. [CrossRef]

98. Kim, P.I.; Sohng, J.K.; Sung, C.; Joo, H.S.; Kim, E.M.; Yamaguchi, T.; Park, D.; Kim, B.G. Characterization and structure identification of an antimicrobial peptide, hominicin, produced by Staphylococcus hominis MBBL 2-9. Biochem. Biophys. Res. Commun. 2010, 399, 133-138. [CrossRef]

99. Fagundes, P.C.; Ceotto, H.; Potter, A.; Vasconcelos Paiva Brito, M.A.; Brede, D.A.; Nes, I.F.; de Freire Bastos, M.C. Hyicin 3682, a bioactive peptide produced by Staphylococcus hyicus 3682 with potential applications for food preservation. Res. Microbiol. 2011, 162, 1052-1059. [CrossRef]

100. Fagundes, P.C.; Nascimento de Sousa Santos, I.; Silva Mrancisco, M.; Mattos Albano, R.; de Freire Bastos, M.D. Genetic and biochemical characterization of hyicin 3682, the first bacteriocin reported for Staphylococcus hyicus. Microbiol. Res. 2017, 198, 36-46. [CrossRef]

101. Islam, M.R.; Nishie, M.; Nagao, J.I.; Zendo, T.; Keller, S.; Nakayama, J.; Kohda, D.; Sahl, H.G.; Sonomoto, K. Ring A of nukacin ISK-1: A lipid II-binding motif for type-A(II) lantibiotic. J. Am. Chem. Soc. 2012, 134, 3687-3690. [CrossRef]

102. Minamikawa, M.; Kawai, Y.; Inoue, N.; Yamazaki, K. Purification and characterization of warnericin RB4, anti-Alicyclobacillus bacteriocin, produced by Staphylococcus warneri RB4. Curr. Microbiol. 2005, 51, $22-26$. [CrossRef] [PubMed]

103. Duarte, A.F.S.; Ceotto-Vigoder, H.; Barrias, E.S.; Souto-Padrón, T.C.B.S.; Nes, I.F.; Bastos, M.D.C.F. Hyicin 4244, the first sactibiotic described in staphylococci, exhibits an anti-staphylococcal biofilm activity. Int. J. Antimicrob. Agents 2018, 51, 349-356. [CrossRef] [PubMed]

104. Netz, D.J.; Sahl, H.G.; Marcolino, R.; dos Santos Nascimento, J.; de Oliveira, S.S.; Soares, M.B.; do Carmo de Freire Bastos, M. Molecular characterisation of aureocin A70, a multi-peptide bacteriocin isolated from Staphylococcus aureus. J. Mol. Biol. 2001, 311, 939-949. [CrossRef]

105. Lynch, D.; O'Connor, P.M.; Cotter, P.D.; Hill, C.; Field, D.; Begley, M. Identification and characterisation of capidermicin, a novel bacteriocin produced by Staphylococcus capitis. PLoS ONE 2019, 14, e0223541. [CrossRef]

106. Gibreel, T.M.; Upton, M. Synthetic epidermicin NI01 can protect Galleria mellonella larvae from infection with Staphylococcus aureus. J. Antimicrob. Chemother. 2013, 68, 2269-2273. [CrossRef] [PubMed]

107. Halliwell, S.; Warn, P.; Sattar, A.; Derrick, J.P.; Upton, M. A single dose of epidermicin NI01 is sufficient to eradicate MRSA from the nares of cotton rats. J. Antimicrob. Chemother. 2017, 72, 778-781. [CrossRef]

108. Sugai, M.; Fujiwara, T.; Akiyama, T.; Ohara, M.; Komatsuzawa, H.; Inoue, S.; Suginaka, H. Purification and molecular characterization of glycylglycine endopeptidase produced by Staphylococcus capitis EPK1. J. Bacteriol. 1997, 179, 1193-1202. [CrossRef]

109. Patron, R.L.; Climo, M.W.; Goldstein, B.P.; Archer, G.L. Lysostaphin treatment of experimental aortic valve endocarditis caused by a Staphylococcus aureus isolate with reduced susceptibility to vancomycin. Antimicrob. Agents Chemother. 1999, 43, 1754-1755. [CrossRef]

110. Quickel, K.E.; Selden, R.; Caldwell, J.R.; Nora, N.F.; Schaffner, W. Efficacy and safety of topical lysostaphin treatment of persistent nasal carriage of Staphylococcus aureus. Appl. Microbiol. 1971, 22, 446-450. [CrossRef]

111. Shah, A.; Mond, J.; Walsh, S. Lysostaphin-coated catheters eradicate Staphylococccus aureus challenge and block surface colonization. Antimicrob. Agents Chemother. 2004, 48, 2704-2707. [CrossRef]

112. Dixon, R.E.; Goodman, J.S.; Koenig, M.G. Lysostaphin: An enzymatic approach to staphylococcal disease. Yale J. Biol. Med. 1968, 41, 62-68.

113. Harrison, E.F.; Zygmunt, W.A. Lysostaphin in experimental renal infections. J. Bacteriol. 1967, 93, 520-524. [CrossRef]

114. Zygmunt, W.A.; Harrison, E.F.; Browder, H.P.; Tavormina, P.A. Comparative inhibition of methicillin-resistant strains of Staphylococcus aureus by lysostaphin and other antibiotics. Appl. Microbiol. 1968, 16, 1174-1178. [CrossRef] [PubMed] 
115. Wu, J.A.; Kusuma, C.; Mond, J.J.; Kokai-Kun, J.F. Lysostaphin disrupts Staphylococcus aureus and Staphylococcus epidermidis biofilms on artificial surfaces. Antimicrob. Agents Chemother. 2003, 47, 3407-3414. [CrossRef] [PubMed]

116. Huber, M.M.; Huber, T.W. Susceptibility of methicillin-resistant Staphylococcus aureus to lysostaphin. J. Clin. Microbiol. 1989, 27, 1122-1124. [CrossRef] [PubMed]

117. Bramley, A.J.; Foster, R. Effects of lysostaphin on Staphylococcus aureus infections of the mouse mammary gland. Res. Vet. Sci. 1990, 49, 120-121. [CrossRef]

118. Schuhardt, V.T.; Schindler, C.A. Lysostaphin therapy in mice infected with Staphylococcus aureus. J. Bacteriol. 1964, 88, 815-816. [CrossRef] [PubMed]

119. Placencia, F.X.; Kong, L.; Weisman, L.E. Treatment of methicillin-resistant Staphylococcus aureus in neonatal mice: Lysostaphin versus vancomycin. Pediatr. Res. 2009, 65, 420-424. [CrossRef]

120. Balouiri, M.; Sadiki, M.; Ibnsouda, S.K. Methods for In Vitro evaluating antimicrobial activity: A review. J. Pharm. Anal. 2016, 6, 71-79. [CrossRef]

121. Manosroi, A.; Khanrin, P.; Lohcharoenkal, W.; Werner, R.G.; Götz, F.; Manosroi, W.; Manosroi, J. Transdermal absorption enhancement through rat skin of gallidermin loaded in niosomes. Int. J. Pharm. 2010, 392, 304-310. [CrossRef]

122. O'Sullivan, J.; O'Connor, P.; Rea, M.; O'Sullivan, O.; Walsh, C.; Healy, B.; Mathur, H.; Field, D.; Hill, C.; Paul, R. Nisin J, a novel natural nisin variant, is produced by Staphylococcus capitis sourced from the human skin microbiota. J. Bacteriol. 2019, 202. [CrossRef]

123. Hurst, A. Nisin. Adv. Appl. Microbiol. 1981, 27, 85-123.

124. Gross, E.; Morell, J.L. The Structure of Nisin. J. Am. Chem. Soc. 1971, 93, 4634-4635. [CrossRef] [PubMed]

125. Zendo, T.; Fukao, M.; Ueda, K.; Higuchi, T.; Nakayama, J.; Sonomoto, K. Identification of the lantibiotic nisin q, a new natural nisin variant produced by Lactococcus lactis 61-14 isolated from a river in Japan. Biosci. Biotechnol. Biochem. 2003, 67, 1616-1619. [CrossRef] [PubMed]

126. Wirawan, R.E.; Klesse, N.A.; Jack, R.W.; Tagg, J.R. Molecular and genetic characterization of a novel nisin variant produced by Streptococcus uberis. Appl. Environ. Microbiol. 2006, 72, 1148-1156. [CrossRef]

127. O'Connor, P.M.; O'Shea, E.F.; Guinane, C.M.; O'Sullivan, O.; Cotter, P.D.; Ross, R.P.; Hill, C. Nisin H is a new nisin variant produced by the gut-derived strain streptococcus hyointestinalis DPC6484. Appl. Environ. Microbiol. 2015, 81, 3953-3960. [CrossRef]

128. De Kwaadsteniet, M.; Ten Doeschate, K.; Dicks, L.M.T. Characterization of the structural gene encoding nisin F, a new lantibiotic produced by a Lactococcus lactis subsp. lactis isolate from freshwater catfish (Clarias gariepinus). Appl. Environ. Microbiol. 2008, 74, 547-549. [CrossRef] [PubMed]

129. Bannoehr, J.; Guardabassi, L. Staphylococcus pseudintermedius in the dog: Taxonomy, diagnostics, ecology, epidemiology and pathogenicity. Vet. Dermatol. 2012, 23, 253-266. [CrossRef] [PubMed]

130. Kadlec, K.; Schwarz, S.; Perreten, V.; Andersson, U.G.; Finn, M.; Greko, C.; Moodley, A.; Kania, S.A.; Frank, L.A.; Bemis, D.A.; et al. Molecular analysis of methicillinresistant Staphylococcus pseudintermedius of feline origin from different European countries and North America. J. Antimicrob. Chemother. 2010, 65, 1826-1828. [CrossRef]

131. Frank, L.A.; Loeffler, A. Meticillin-resistant Staphylococcus pseudintermedius: Clinical challenge and treatment options. Vet. Dermatol. 2012, 23, 283-291. [CrossRef] [PubMed]

132. McCarthy, A.J.; Harrison, E.M.; Stanczak-Mrozek, K.; Leggett, B.; Waller, A.; Holmes, M.A.; Lloyd, D.H.; Lindsay, J.A.; Loeffler, A. Genomic insights into the rapid emergence and evolution of MDR in Staphylococcus pseudintermedius. J. Antimicrob. Chemother. 2014, 70, 997-1007. [CrossRef] [PubMed]

133. Barré-Sinoussi, F.; Montagutelli, X. Animal models are essential to biological research: Issues and perspectives. Future Sci. OA 2015, 1. [CrossRef]

134. Hoffmann, J.A. Innate immunity of insects. Curr. Opin. Immunol. 1995, 7, 4-10. [CrossRef]

135. Kokai-Kun, J.F. The cotton rat as a model for Staphylococcus aureus nasal colonization in humans: Cotton Rat S. aureus Nasal Colonization Model. Methods Mol. Biol. 2007, 431, 241-254.

136. Kumar, R.; Jangir, P.K.; Das, J.; Taneja, B.; Sharma, R. Genome Analysis of Staphylococcus capitis TE8 Reveals Repertoire of Antimicrobial Peptides and Adaptation Strategies for Growth on Human Skin. Sci. Rep. 2017, 7, 10447. [CrossRef] [PubMed] 
137. Khusro, A.; Aarti, C.; Salem, A.Z.M.; Buendía Rodríguez, G.; Rivas-Cáceres, R.R. Antagonistic trait of Staphylococcus succinus strain AAS2 against uropathogens and assessment of its in vitro probiotic characteristics. Microb. Pathog. 2018, 118, 126-132. [CrossRef] [PubMed]

138. Rahmdel, S.; Shekarforoush, S.S.; Hosseinzadeh, S.; Torriani, S.; Gatto, V. Antimicrobial spectrum activity of bacteriocinogenic Staphylococcus strains isolated from goat and sheep milk. J. Dairy Sci. 2019, 102, 2928-2940. [CrossRef]

139. Janek, D.; Zipperer, A.; Kulik, A.; Krismer, B.; Peschel, A. High Frequency and Diversity of Antimicrobial Activities Produced by Nasal Staphylococcus Strains against Bacterial Competitors. PLoS Pathog. 2016, 12, e1005812. [CrossRef]

140. Carson, D.A.; Barkema, H.W.; Naushad, S.; De Buck, J. Bacteriocins of non-aureus staphylococci isolated from bovine milk. Appl. Environ. Microbiol. 2017, 83, 1-21. [CrossRef]

141. Blin, K.; Shaw, S.; Steinke, K.; Villebro, R.; Ziemert, N.; Lee, S.Y.; Medema, M.H.; Weber, T. antiSMASH 5.0: Updates to the secondary metabolite genome mining pipeline. Nucleic Acids Res. 2019, 47, W81-W87. [CrossRef]

142. de Jong, A.; van Hijum, S.A.F.T.; Bijlsma, J.J.E.; Kok, J.; Kuipers, O.P. BAGEL: A web-based bacteriocin genome mining tool. Nucleic Acids Res. 2006, 34, W273-W279. [CrossRef] [PubMed]

143. Iwase, T.; Uehara, Y.; Shinji, H.; Tajima, A.; Seo, H.; Takada, K.; Agata, T.; Mizunoe, Y. Staphylococcus epidermidis Esp inhibits Staphylococcus aureus biofilm formation and nasal colonization. Nature 2010, 465, 346-349. [CrossRef] [PubMed]

144. Chen, C.; Krishnan, V.; Macon, K.; Manne, K.; Narayana, S.V.L.; Schneewind, O. Secreted proteases control autolysin-mediated biofilm growth of Staphylococcus aureus. J. Biol. Chem. 2013, 288, 29440-29452. [CrossRef] [PubMed]

145. Mann, E.E.; Rice, K.C.; Boles, B.R.; Endres, J.L.; Ranjit, D.; Chandramohan, L.; Tsang, L.H.; Smeltzer, M.S.; Horswill, A.R.; Bayles, K.W. Modulation of eDNA release and degradation affects Staphylococcus aureus biofilm maturation. PLoS ONE 2009, 4, e5822. [CrossRef] [PubMed]

146. Huseby, M.J.; Kruse, A.C.; Digre, J.; Kohler, P.L.; Vocke, J.A.; Mann, E.E.; Bayles, K.W.; Bohach, G.A.; Schlievert, P.M.; Ohlendorf, D.H.; et al. Beta toxin catalyzes formation of nucleoprotein matrix in staphylococcal biofilms. Proc. Natl. Acad. Sci. USA 2010, 107, 14407-14412. [CrossRef] [PubMed]

147. Sugimoto, S.; Iwamoto, T.; Takada, K.; Okuda, K.I.; Tajima, A.; Iwase, T.; Mizunoe, Y. Staphylococcus epidermidis Esp degrades specific proteins associatedwith Staphylococcus aureus biofilm formation and host-pathogen interaction. J. Bacteriol. 2013, 195, 1645-1655. [CrossRef]

148. Zipperer, A.; Konnerth, M.C.; Laux, C.; Berscheid, A.; Janek, D.; Weidenmaier, C.; Burian, M.; Schilling, N.A.; Slavetinsky, C.; Marschal, M.; et al. Human commensals producing a novel antibiotic impair pathogen colonization. Nature 2016, 535, 511-516. [CrossRef]

(C) 2020 by the authors. Licensee MDPI, Basel, Switzerland. This article is an open access article distributed under the terms and conditions of the Creative Commons Attribution (CC BY) license (http://creativecommons.org/licenses/by/4.0/). 